\title{
RESEARCH
}

Open Access

\section{Paracrine stimulation of perinatal lung functional and structural maturation by mesenchymal stem cells}

\author{
Janine Obendorf ${ }^{1}$, Claire Fabian², Ulrich H. Thome ${ }^{1}$ and Mandy Laube ${ }^{1 *}$ (D)
}

\begin{abstract}
Background: Mesenchymal stem cells (MSCS) were shown to harbor therapeutic potential in models of respiratory diseases, such as bronchopulmonary dysplasia (BPD), the most common sequel of preterm birth. In these studies, cells or animals were challenged with hyperoxia or other injury-inducing agents. However, little is known about the effect of MSCs on immature fetal lungs and whether MSCs are able to improve lung maturity, which may alleviate lung developmental arrest in BPD.

Methods: We aimed to determine if the conditioned medium (CM) of MSCs stimulates functional and structural lung maturation. As a measure of functional maturation, $\mathrm{Na}^{+}$transport in primary fetal distal lung epithelial cells (FDLE) was studied in Ussing chambers. $\mathrm{Na}^{+}$transporter and surfactant protein mRNA expression was determined by qRT-PCR. Structural maturation was assessed by microscopy in fetal rat lung explants.

Results: MSC-CM strongly increased the activity of the epithelial $\mathrm{Na}^{+}$channel (ENaC) and the Na,K-ATPase as well as their mRNA expression. Branching and growth of fetal lung explants and surfactant protein mRNA expression were enhanced by MSC-CM. Epithelial integrity and metabolic activity of FDLE cells were not influenced by MSCCM. Since MSC's actions are mainly attributed to paracrine signaling, prominent lung growth factors were blocked. None of the tested growth factors (VEGF, BMP, PDGF, EGF, TGF- $\beta$, FGF, HGF) contributed to the MSC-induced increase of $\mathrm{Na}^{+}$transport. In contrast, inhibition of PI3-KAKT and Rac1 signaling reduced MSC-CM efficacy, suggesting an involvement of these pathways in the MSC-CM-induced $\mathrm{Na}^{+}$transport.

Conclusion: The results demonstrate that MSC-CM strongly stimulated functional and structural maturation of the fetal lungs. These effects were at least partially mediated by the PI3-K/AKT and Rac1 signaling pathway. Thus, MSCs not only repair a deleterious tissue environment, but also target lung cellular immaturity itself.
\end{abstract}

Keywords: Mesenchymal stem cells, Fetal lung maturation, Epithelial sodium channel, $\mathrm{Na}^{+}$transport, Preterm infants, Respiratory distress

\footnotetext{
*Correspondence: mandy.laube@medizin.uni-leipzig.de

${ }^{1}$ Center for Pediatric Research Leipzig, Department of Pediatrics, Division of Neonatology, University of Leipzig, Liebigstrasse 19, 04103 Leipzig, Germany Full list of author information is available at the end of the article
}

(c) The Author(s). 2020 Open Access This article is licensed under a Creative Commons Attribution 4.0 International License, which permits use, sharing, adaptation, distribution and reproduction in any medium or format, as long as you give appropriate credit to the original author(s) and the source, provide a link to the Creative Commons licence, and indicate if changes were made. The images or other third party material in this article are included in the article's Creative Commons licence, unless indicated otherwise in a credit line to the material. If material is not included in the article's Creative Commons licence and your intended use is not permitted by statutory regulation or exceeds the permitted use, you will need to obtain permission directly from the copyright holder. To view a copy of this licence, visit http://creativecommons.org/licenses/by/4.0/ The Creative Commons Public Domain Dedication waiver (http://creativecommons.org/publicdomain/zero/1.0/) applies to the data made available in this article, unless otherwise stated in a credit line to the data. 


\section{Background}

Lung maturation is a complex process that is influenced by a variety of factors. Growth factor signaling as well as ion channel functions are crucially involved in intrauterine lung proliferation and differentiation. During fetal development, the lung undergoes extensive changes in fluid secretion and absorption [1]. Fluid transport across alveolar epithelial cells is mediated by $\mathrm{Na}^{+}$influx through epithelial $\mathrm{Na}^{+}$channels $(\mathrm{ENaC})$ in the apical membrane [2]. At the basolateral side, $\mathrm{Na}^{+}$is actively extruded by the Na,K-ATPase, generating an osmotic gradient that drives fluid diffusion across the alveolar epithelium [3]. Vectorial $\mathrm{Na}^{+}$transport is regulated by several pathways, including steroids [4], growth factors $[5,6]$, and kinase signaling $[7,8]$. Furthermore, the surfactant is secreted by mature alveolar type II (ATII) cells to prevent alveolar collapse during end-expiration [9]. Disruption of $\mathrm{Na}^{+}$transport-driven alveolar fluid clearance (AFC) and insufficient surfactant secretion due to preterm birth can lead to serious pulmonary complications and respiratory distress.

Among them, bronchopulmonary dysplasia (BPD) is a severe neonatal chronic lung disease first described by Northway and colleagues in 1967 [10]. The so-called "old" BPD was characterized by intense inflammation, fibrosis, and lung injury due to disruption of pulmonary structures [11]. In contrast, advances in neonatal care (surfactant therapy, optimized ventilation) and survival of extremely preterm infants have changed the disease pathology [12]. The "new" BPD is characterized predominantly by simplified lung structure with fewer and larger alveoli, especially in extremely preterm infants born at earlier gestational ages (24-27 weeks) [12, 13]. BPD is a multifactorial disease and a variety of therapeutic strategies have been exerted; however, current treatment options are mainly palliative, and until now, no promising pharmacological approach exists to prevent or cure the disease [14].

An increased interest in stem cells has emerged in recent years. Mesenchymal stem cells (MSCs) are multipotent cells found in a variety of adult tissues, such as the adipose tissue, bone marrow, amniotic fluid, placenta, or umbilical cord, the latter containing MSCs in the cord lining membrane as well as in Wharton's jelly $[15,16]$. The efficacy of cell-based therapies is mainly attributed to paracrine signaling [17]. MSCs secrete immunomodulatory factors and several growth factors including fibroblast growth factor (FGF), hepatocyte growth factor (HGF), epidermal growth factor (EGF), and vascular endothelial growth factor (VEGF) [18]. MSC-based studies have shown beneficial effects in animal models of BPD. Administration of bone marrow (BM)-derived MSCs and its conditioned medium for example ameliorated parenchymal and vascular injury in neonatal mice exposed to hyperoxia [19]. Furthermore, BM-derived MSCs lowered pulmonary hypertension, improved survival, and preserved alveolar and vascular growth in hyperoxia-exposed rat pups [20]. MSCs also stimulated branching morphogenesis of fetal rat lung explants [21] and increased lung organoid formation and alveolar differentiation in 3D progenitor cell cultures [22]. Thus, the in vitro and in vivo studies showed promising results of MSC application, but focused mainly on the repair of disease pathways by counteracting inflammation and oxygen toxicity. In contrast, few studies have investigated the effect of MSCs on lung maturation. It is yet unknown whether or not MSCs stimulate lung maturation in immature fetal lungs prior to disease onset. Since improving lung immaturity may be an effective strategy to enhance lung development and function in preterm infants, the aim of the present study was to elucidate maturational responses of fetal distal lung epithelial cells (FDLE) exposed to conditioned medium of MSCs (MSC-CM). Epithelial $\mathrm{Na}^{+}$transport and structural maturation of fetal lung explants were studied as markers of maturation. Furthermore, the involved pathways of MSC's effects were investigated by inhibiting several growth factor receptors and kinases. Our findings support the hypothesis that MSCs constitute a therapeutic option for respiratory distress in preterm infants by elevating AFC and structural lung maturation involving kinase and Rho-GTPase signaling.

\section{Methods}

\section{Cell isolation and culture}

Isolation and characterization of human MSCs

The study was approved by the ethical board of the medical faculty of Leipzig University. The umbilical cord (UC) tissue was collected after delivery from newborns whose mothers granted informed consent. MSC isolation and characterization are described in the Supplements.

\section{Isolation of FDLE cells}

All animal care and experimental procedures were approved by the institutional review board (Landesdirektion Leipzig, Permit number: T23/15). Sprague-Dawley rats were bred at the Medical Experimental Center (MEZ) of Leipzig University and housed in rooms with a controlled temperature of $22^{\circ} \mathrm{C}, 55 \%$ humidity, and a 12-h light-dark cycle. Food and water were freely available. Rats were euthanized by Pentobarbital injection.

FDLE cells were isolated at gestational day 19 to 20 from rat fetuses as described elsewhere [23-25]. Briefly, the fetal lungs were minced and digested in Hanks' Balanced Salt Solution (Life Technologies, Carlsbad, USA), containing $0.125 \%$ trypsin (Life Technologies), and $0.4 \mathrm{mg} / \mathrm{ml}$ DNAse (Merck, Darmstadt, Germany) for $10 \mathrm{~min}$ at $37^{\circ} \mathrm{C}$. Digestion was stopped with MEM (Life 
Technologies) supplemented with 10\% FBS. The cell suspension was centrifuged twice and the pellet resuspended in MEM. After centrifugation, cells were resuspended in MEM containing $0.1 \%$ collagenase type I (CellSystems, Troisdorf, Germany) and $0.2 \mathrm{mg} / \mathrm{ml}$ DNAse and incubated for $15 \mathrm{~min}$ at $37^{\circ} \mathrm{C}$. After adding MEM with 10\% FBS (Biochrom, Berlin, Germany), the cell suspension was centrifuged and resuspended in MEM containing 10\% FBS, and plated twice in cell culture flasks at $37^{\circ} \mathrm{C}$ for $1 \mathrm{~h}$ to remove contaminating fibroblasts. For Ussing chamber studies, the cells were seeded on permeable Snapwell inserts with a surface area of $1.1 \mathrm{~cm}^{2}$ (Costar, \#3407, Corning Inc., NY, USA) at a density of $10^{6}$ per insert. For RNA isolation, the cells were seeded on cell culture inserts with a surface area of $4.6 \mathrm{~cm}^{2}$ (ThinCert, \#657641, Greiner Bio-One, Frickenhausen, Germany) at a density of $2 \times 10^{6}$ cells per insert. FDLE cells were cultured submerged in MEM with $10 \%$ FBS, L-glutamine (2 mM, Merck), penicillin, streptomycin, and amphotericin $\mathrm{B}$, with daily media exchange. $24 \mathrm{~h}$ prior to measurements the FDLE cell medium was either replaced by MSC-CM or control medium, containing DMEM (low glucose, GlutaMAX ${ }^{\mathrm{m}}$ ) with $2 \% \mathrm{FBS}$, accordingly. For receptor tyrosine kinase (RTK) inhibition, the respective inhibitor was added to the culture medium $24 \mathrm{~h}$ before analysis. The inhibitors of the VEGF receptor (Axitinib, $10 \mu \mathrm{M}$ ), the bone morphogenetic protein receptor (BMP-R; K02288, $1 \mu \mathrm{M}$ ), the plateletderived growth factor receptor (PDGF-R; AG-1296, $10 \mu \mathrm{M}$ ), the EGF receptor (EGF-R; AG-1478, $1 \mu \mathrm{M}$ ), the transforming growth factor $\beta$ receptor (TGF- $\beta-R$; SB431542, $1 \mu \mathrm{M}$ ), the FGF receptor (FGF-R; FIIN-2, $1 \mu \mathrm{M}$ ), and the HGF receptor c-met (PHA665752, $1 \mu \mathrm{M}$ ) were purchased from Biomol (Hamburg, Germany). The inhibitor of the Ras-related C3 botulinum toxin substrate 1 (Rac1; Ehop-016, $1 \mu \mathrm{M}$ ) was obtained from Selleckchem (Houston, USA). The inhibitors of the phosphoinositide 3-kinase (PI3-K; LY294002, $10 \mu \mathrm{M}$ ) and the protein kinase B (AKT; Akti $1 / 2,10 \mu \mathrm{M})$ were purchased from Merck. Inhibitors were dissolved in DMSO, and the respective controls were treated with the solvent to exclude any solvent influence on the evoked responses.

\section{Fetal lung isolation for explant culture}

Fetal rat lungs were isolated at embryonic day (ED) 15 of gestation from Sprague-Dawley fetuses according to the protocol of del Moral et al. [26]. For explant cultivation, the lungs were incubated on cell culture inserts at an air-liquid-interface for an additional 4 days. The culture medium was changed daily, and growth was documented with a Zeiss Axio Zoom.V16 Stereo Microscope (Zeiss, Oberkochen, Germany). Every experiment was repeated at least three times with a minimum of three lungs per group. To calculate total lung explant and tissue area, microscopic pictures of the whole lungs, or hematoxylin and eosin (HE)-stained whole lung slices were analyzed with ImageJ software (National Institutes of Health, Bethesda, USA). ImageJ macros used for area analysis are illustrated in the Supplements. The number of peripheral airway buds was counted on the day of isolation (ED15) and 2 days later (ED15 + 2). In addition, the ratio of the increase in airway bud number from ED15 to ED15 + 2 was calculated, as described elsewhere [27].

\section{Immunofluorescence staining of fetal lung explants}

For immunofluorescence staining, lung explants were fixed with $4 \%$ formaldehyde in PBS for $2 \mathrm{~h}$ at $4{ }^{\circ} \mathrm{C}$. Upon fixation, frozen sections of $6 \mu \mathrm{m}$ were cut and slides stored at $-20^{\circ} \mathrm{C}$. After treatment with blocking solution (5\% BSA in $0.3 \%$ Triton X-100/PBS) for $1 \mathrm{~h}$, lung explant slices were incubated with rabbit anti-epithelial cell adhesion molecule (EpCAM) primary antibody (1:50 in blocking solution; Abcam, Cambridge, UK) at $4{ }^{\circ} \mathrm{C}$ overnight. The secondary antibody anti-rabbit (Northern Lights $^{\text {tx }}$ NL493 conjugated, 1:200 in blocking solution; R\&D Systems, Boston, USA) was applied for $2 \mathrm{~h}$. Nuclei were stained with DAPI $(1 \mu \mathrm{g} / \mathrm{ml})$. Immunofluorescence staining was analyzed with confocal laser-scanning microscopy (LSM710; Zeiss).

\section{Cell permeability assay}

To assess epithelial permeability, FDLE cells were cultivated on Snapwell inserts. After 2 days of culture, the medium was changed to MSC-CM or control medium for $24 \mathrm{~h}$. Afterwards, the medium was replaced by phenol red-free MEM (Life Technologies) in the lower compartment and phenol red-free MEM containing FITCdextran $(0.25 \mathrm{mg} / \mathrm{ml}, 3-5 \mathrm{kDa}$, Merck) in the upper compartment. After incubation of cells at $37^{\circ} \mathrm{C}$ for another $24 \mathrm{~h}$, the medium of the lower compartment was analyzed for fluorescence intensity of FITC-dextran. A standard dilution series of FITC-dextran was used for quantification.

\section{Ussing chamber measurements}

All Ussing chamber experiments were performed 4 days after seeding FDLE on Snapwell inserts with an EMCSYS-8 EasyMount Ussing chamber system (Physiological Instruments, San Diego, CA, USA) at $37{ }^{\circ} \mathrm{C}$ and continuous gas supply with $5 \% \mathrm{CO}_{2}$ and $95 \% \mathrm{O}_{2}$. Ussing chambers were filled with Ringer solution containing: $145 \mathrm{mM}$ $\mathrm{Na}^{+}, 5 \mathrm{mM} \mathrm{K}^{+}, 1.2 \mathrm{mM} \mathrm{Ca}^{2+}, 1.2 \mathrm{mM} \mathrm{Mg}^{2+}, 125 \mathrm{mM} \mathrm{Cl}^{-}$, $25 \mathrm{mM} \mathrm{HCO}_{3}{ }^{-}, 3.3 \mathrm{mM} \mathrm{H}_{2} \mathrm{PO}_{4}{ }^{-}$, and $0.8 \mathrm{mM} \mathrm{HPO}_{4}{ }^{2-}$ (pH 7.4). On the basolateral side, $10 \mathrm{mM}$ glucose and on the apical side $10 \mathrm{mM}$ mannitol were used. Measurements with a transepithelial resistance $\left(R_{\mathrm{te}}\right)$ below $300 \Omega^{*} \mathrm{~cm}^{2}$ 
were excluded from analyses. Equivalent short-circuit currents $\left(I_{\mathrm{SC}}\right)$ were assessed every $20 \mathrm{~s}$ by measuring transepithelial potential difference $\left(V_{\mathrm{te}}\right)$ and $R_{\mathrm{te}}$ with a transepithelial current clamp and calculating the quotient $I_{\mathrm{SC}}=V_{\mathrm{te}} / R_{\mathrm{te}}$. After the baseline $I_{\mathrm{SC}}$ reached a stable plateau ( $\left.I_{\text {base }}\right)$, amiloride $(10 \mu \mathrm{M}$, \# A7410, Merck) was added to the apical compartment to determine the amiloridesensitive $\Delta I_{\mathrm{SC}}\left(\Delta I_{\text {amil }}\right)$.

To determine the maximal ENaC activity (amil $\left.l_{\max }\right), 140$ $\mathrm{mM}$ of basolateral $\mathrm{Na}^{+}$was replaced by $116 \mathrm{mMN}$-methyl-D-glucamine (NMDG ${ }^{+}, \# \mathrm{M}-2004$, Sigma-Aldrich) and $24 \mathrm{mM}$ choline, generating a $145: 5$ apical-tobasolateral $\mathrm{Na}^{+}$gradient. Then, the $I_{\mathrm{SC}}$ was measured every $5 \mathrm{~s}$ with a transepithelial voltage clamp. The basolateral membrane was permeabilized with amphotericin B (100 $\mu \mathrm{M}$, Merck), uncoupling the Na,K-ATPase. When the maximum current increase was reached, amiloride was added to the apical compartment to determine amilmax. On the other hand, $o u a b_{\max }$ represents the maximum activity of the Na,K-ATPase. To determine $o u a b_{\max }$, the apical membrane was permeabilized with amphotericin $\mathrm{B}$ $(10 \mu \mathrm{M})$. When the $I_{\mathrm{SC}}$ had reached its maximum value, the Na,K-ATPase inhibitor ouabain ( $1 \mathrm{mM}$, Merck) was added to the basolateral compartment. The ouabainsensitive component of the amphotericin-induced maximal $I_{\mathrm{SC}}\left(\right.$ ouab $\left._{\max }\right)$ was calculated, accordingly.

\section{Gene expression analyses}

Total RNA was isolated 5 days after seeding of the FDLE cells using the PureLink ${ }^{\text {Tx }}$ RNA Kit (ThermoFisher) according to the manufacturers' protocol. For elimination of genomic DNA and cDNA synthesis, the Maxima $\mathrm{H}$ Minus First-Strand cDNA Synthesis Kit, with dsDNase (ThermoFisher), was used. The total RNA $(1 \mu \mathrm{g})$ was reversely transcribed and cDNA further diluted 1:10 in Tris-EDTA (Applichem). Real-time quantitative PCR (qPCR) analyses were conducted with the CFX Connect ${ }^{\mathrm{m}}$ Real-Time PCR Detection System (BioRad, Hercules, USA) using SYBR ${ }^{\mathrm{mu}}$ Select Mastermix for CFX (ThermoFisher) and gene-specific primers [4, 28]. In each qPCR run, at least three biological and four technical replicates were analyzed. Serial dilutions of target-specific plasmid DNA were used for absolute quantification. Target gene expression was normalized using the reference gene mitochondrial ribosomal protein S18a (Mrps18a). Constant expression of Mrps18a was confirmed against other common reference genes.

\section{MTT}

Metabolic activity in FDLE cells was determined with 3(4,5-dimethylthiazol-2-yl)-2,5-diphenyltetrazolium bromide (MTT) assays. To this end, the medium was changed to a culture medium containing $5 \mathrm{mg} / \mathrm{ml}$ Thiazolyl Blue Tetrazolium Bromide solution (Applichem, Darmstadt,
Germany). After an incubation period of $4 \mathrm{~h}$ at $37^{\circ} \mathrm{C}$, the medium was discarded and the reaction stopped with a solution containing 1:1 dimethylformamide and $20 \%$ SDS (Roth, Karlsruhe, Germany). After $1 \mathrm{~h}$ incubation at $37^{\circ} \mathrm{C}$, formazan crystals were dissolved, and the supernatant analyzed at $570 \mathrm{~nm}$.

\section{Statistical analysis}

Differences between two groups were analyzed with the unpaired $t$ test. Otherwise, significant differences were determined by a one-way ANOVA with Tukey's post hoc test. A probability of $p<0.05$ was considered significant for all statistical analyses. Statistical analysis was conducted using GraphPad Prism Software (version 5.03, Graph Pad software, Inc., San Diego, CA, USA).

\section{Results}

\section{UC-MSC characterization}

According to the minimal criteria defined by the International Society for Cellular Therapy, we analyzed the surface marker expression and tri-lineage differentiation capacity of isolated UC-MSCs to demonstrate their stem cell properties (Fig. S1). The cells strongly expressed the common MSC markers CD44 (94 $\pm 3.15 \%)$, CD73 $(94 \pm 1.39 \%)$, and CD90 (90 $\pm 1.88 \%)$, whereas the expression of hematopoietic markers CD11b $(26 \pm 3.12 \%)$ and CD45 (13 $\pm 2.24 \%)$ was low. Analysis of adipogenic differentiation using Oil red $\mathrm{O}$ staining showed a high number of small intracellular lipid droplets. Staining of acidic polysaccharides with Alcian blue showed that UCMSCs differentiated reliably into chondrogenic cells. Osteogenic differentiation was demonstrated with ALP 1 staining, although the differentiation process was slower (4 weeks) compared to chondrogenic and adipogenic differentiation (2 weeks).

\section{MSC-CM induces functional maturation of FDLE cells}

MSC-CM incubation of FDLE cells for $24 \mathrm{~h}$ significantly elevated $I_{\text {base }}$ and $\Delta I_{\text {amil }}$ 1.4-fold compared with control cells $(p<0.001$, Fig. 1a). MSC-CM further strongly increased amil $l_{\max }$ in FDLE cells compared with control cells $(p<0.01$, Fig. $1 b)$. In addition, maximal $\mathrm{Na}, \mathrm{K}$ ATPase activity was strongly elevated by MSC-CM, as shown by the significantly elevated $o u a b_{\max }$ in FDLE monolayers ( $p<0.001$, Fig. $1 c)$. In conclusion, MSC-CM profoundly increased epithelial $\mathrm{Na}^{+}$transport, as well as the maximal $\mathrm{ENaC}$ and maximal $\mathrm{Na}, \mathrm{K}-\mathrm{ATPase}$ activity in FDLE cells.

MSC-CM-incubated FDLE cells showed a significantly higher mRNA expression of the $\alpha-E N a C, \beta-E N a C$, and $\gamma-E N a C$ subunits compared to control cells $(p<0.01$, $p<0.001$, Fig. 1d). Expression of $\alpha-E N a C$ was 1.6 -fold higher in MSC-CM-treated cells compared to control cells. Furthermore, mRNA expression of $\beta-E N a C$ and $\gamma$ - 


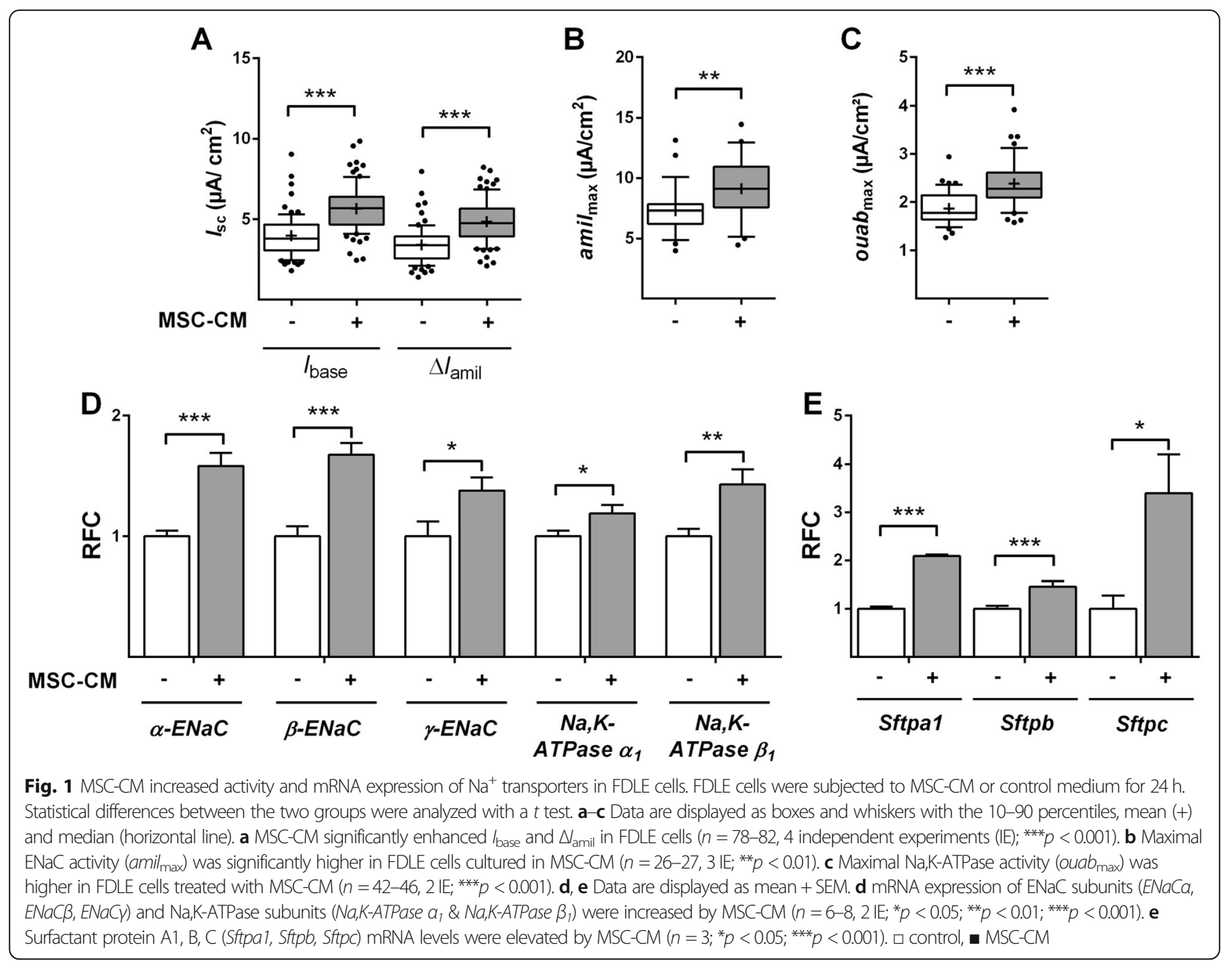

ENaC were 1.7-fold and 1.4-fold higher in FDLE cells cultivated in MSC-CM. In addition, mRNA expression of the Na,K-ATPase subunits $\alpha_{1}$ and $\beta_{1}$ was significantly higher in FDLE cells grown in MSC-CM $(p<0.05, p<$ 0.01 , Fig. 1d). The Na,K-ATPase $\alpha_{1}$ expression level was 1.2-fold higher, while MSC-CM elevated the $\mathrm{Na}, \mathrm{K}$ ATPase $\beta_{1}$ expression 1.4-fold. These results demonstrate that MSC-CM increased mRNA expression of the involved $\mathrm{Na}^{+}$transporters, possibly contributing to the increased $\mathrm{Na}^{+}$transport shown before.

Another important feature of perinatal lung transition and a commonly used marker of lung maturation is the secretion of surfactant by ATII cells. Surfactant proteins $\mathrm{A}, \mathrm{B}$, and $\mathrm{C}$ mRNA expressions were significantly induced by MSC-CM $(p<0.05, p<0.001$, Fig. 1e). Expression of Sftpa1 was 2.1-fold higher than in control cells. Furthermore, Sftpb was 1.5 -fold higher and Sftpc was 3.4-fold higher in MSC-CM-treated compared to control FDLE cells. Herein, another crucial alveolar function was augmented by MSC-CM, further supporting the induction of functional maturation.
MSC-CM enhances the structural maturation of fetal lung explants

Lung explants treated with MSC-CM for 4 days displayed an enhanced branching and structural morphology compared to control explants (Fig. 2a, e). The area of lung explants increased during culture in control and MSC-CM, but MSC-CM significantly raised explant area after 2 and 4 days in culture compared to control explants $(p<0.05, p<0.001$, Fig. 2a, b). To exclude that the growth surge induced by MSC-CM is the result of abnormal tissue expansion like hyperplasia, we analyzed the ratio of tissue area in relation to total lung explant area (circumference) in control and MSC-CM treated lung slices. This ratio represents a size-independent measure of tissue alterations. Notably, the ratio of the tissue to the total lung area was not changed, demonstrating a proportional growth induced by MSC-CM (Fig. 2c). We further calculated the increase of peripheral airway bud numbers from day 0 to day 2 in culture, which was significantly higher in MSC-CM-treated explants $(p<0.05$, Fig. $2 \mathrm{~d}$, e). To exclude possible 


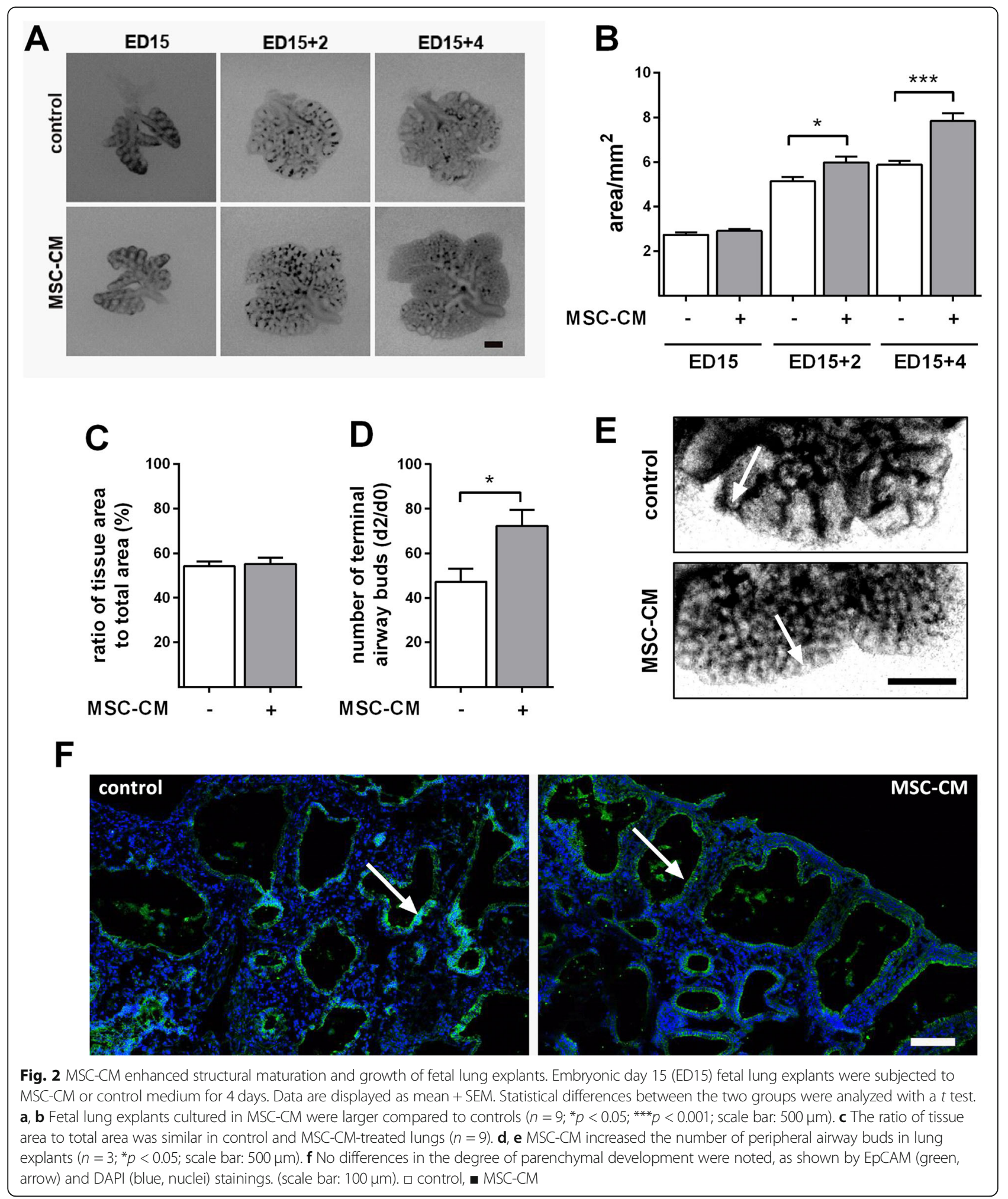

differences in lung explant cell composition, we conducted immunofluorescence staining of EpCAM (Fig. 2f). No obvious abnormal structures were observed in MSCCM-treated lungs. The control lungs as well as the lungs cultured in MSC-CM showed a comparable degree of parenchymal development, which confirms the finding that MSC-CM does not cause abnormal tissue expansion. Taken together, these results support an enhanced 
growth and structural maturation with regard to peripheral airway buds induced by MSC-CM, in addition to the elevated functional activity of fetal alveolar epithelial cells shown above.

\section{Epithelial integrity and metabolic activity are not affected by MSC-CM}

We analyzed whether the epithelial barrier function is altered by MSC-CM in FDLE monolayers. Epithelial permeability was determined with FITC-dextran assays, which showed that permeability of MSC-CM-treated FDLE and control epithelia were not significantly different (Fig. 3a). The $R_{\text {te }}$ of monolayers was equal in the control medium and MSC-CM (Fig. 3b). Metabolic activity was assessed in MTT assays. MTT assays are generally considered to determine the proliferation rate of cells, which was not affected by MSC-CM after $24 \mathrm{~h}$ (Fig. 3c).

\section{MSC-CM-induced $\mathrm{Na}^{+}$transport is not mediated by growth factors}

To determine which pathway MSC-CM increased $\mathrm{Na}^{+}$ transport in FDLE cells, we inhibited several growth factors by blocking their respective cellular receptor. Inhibition of the VEGF-R with Axitinib revealed that VEGF-R signaling is not involved, since MSC-CM was still able to strongly elevate $\Delta I_{\text {amil }}$ compared to control cells $(p<$ 0.001 , Fig. 4a). Similarly, inhibition of BMP-R with K02288 did not prevent the significant increase of $\Delta I_{\text {amil }}$ induced by MSC-CM $(p<0.001$, Fig. 4b). AG-1296, inhibiting the PDGF-R, did also not affect the stimulation of $\Delta I_{\text {amil }}$ induced by MSC-CM $(p<0.001$, Fig. 4c). AG1478, which selectively blocks the EGF-R, significantly decreased $\Delta I_{\text {amil }}$ in both culture conditions; however, MSC-CM was still able to significantly increase $\Delta I_{\text {amil }}$ compared to control cells $(p<0.001$, Fig. $4 \mathrm{~d})$. This indicates that EGF-R inhibition by AG-1478 was nonspecific and probably mediated by a different mechanism independent of MSC-CM components. Similar observations were obtained for the following inhibitors. The TGF- $\beta$-R inhibitor SB431542 decreased $\Delta I_{\text {amil }}$ in both MSC-CM-treated and control cells $(p<0.001$, Fig. 4e). Nevertheless, SB431542 did not prevent the increased $\Delta I_{\text {amil }}$ induced by MSC-CM $(p<0.05)$. Furthermore, inhibition of the FGF-R by FIIN-2 decreased $\Delta I_{\text {amil }}$ in both, MSC-CM-treated and control cells, and MSC-CM significantly increased $\Delta I_{\text {amil }}$ in the presence of FIIN-2 $(p<0.05, p<0.001$, Fig. 4f). In addition, PHA665752 inhibiting the HGF receptor c-Met reduced $\Delta I_{\text {amil }}$ in MSC-CM-treated cells ( $p<0.01$, Fig. 4 g), but MSC-CM significantly elevated $\Delta I_{\text {amil }}$ in the presence of PHA665752 $(p<0.001$ Fig. 4g). Thus, none of the tested growth factor inhibitors specifically blocked the actions of MSC-CM. Therefore, the involved pathways probably did not contribute to the MSC-CM-induced stimulation of $\mathrm{Na}^{+}$transport. Inhibition of the EGF-R, the TGF- $\beta$ - R, the FGF-R, and c-met demonstrated a general involvement in the regulation of $\mathrm{Na}^{+}$transport, while VEGF-R, BMP-R, and PDGF-R lacked any effect. Therefore, the stimulating effect of MSC-CM on $\mathrm{Na}^{+}$transport was not affected by the inhibition of these growth factor pathways. As stated above, we report the equivalent $I_{\mathrm{SC}}$, calculated according to Ohm's law. In accordance with $\Delta I_{\text {amil }}, \Delta V_{\text {amil }}$ confirmed the lack of growth factor contribution to the stimulated $\mathrm{Na}^{+}$transport by MSC-CM (Fig. S2). $R_{\text {te }}$ of the Ussing chamber measurements is also reported in the supplements (Fig. S3).

\section{Kinase signaling via PI3-K/AKT contributes to the MSC- mediated $\mathrm{Na}^{+}$channel activity}

Inhibition of growth factor signaling via their respective receptors did not prevent the stimulating effect of MSC-
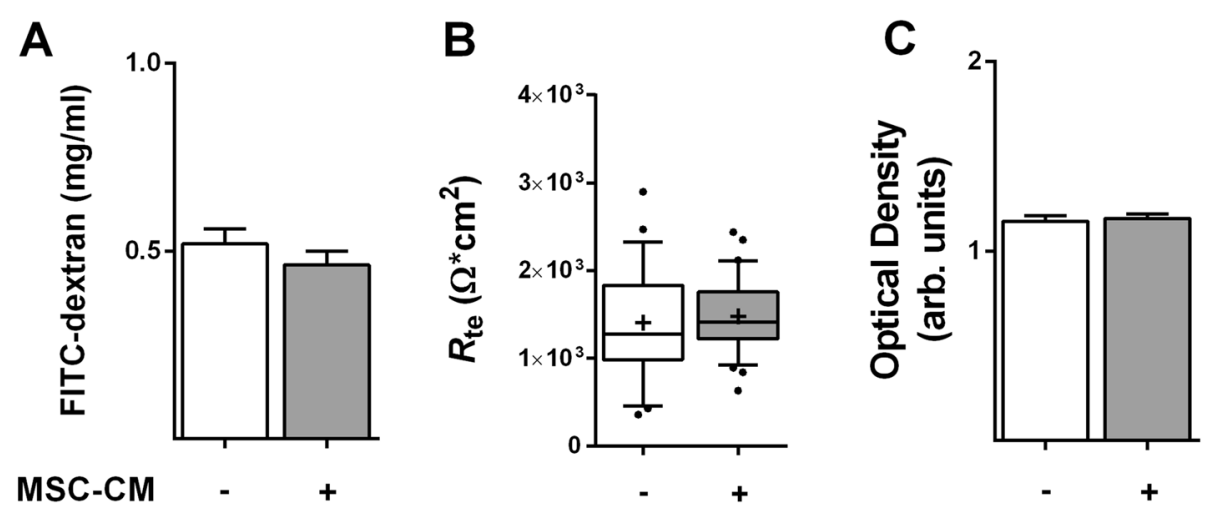

Fig. 3 Epithelial integrity and metabolic activity of FDLE cells were not affected by MSC-CM. FDLE cells were subjected to MSC-CM or control medium for $24 \mathrm{~h}$. Data are displayed as mean + SEM or box and whiskers with the 10-90 percentiles, mean ( + ) and median (horizontal line). Statistical differences between the two groups were analyzed with a $t$ test. a Epithelial integrity was determined with FITC-dextran assays. MSC-CM had no effect on the permeability of FDLE monolayers ( $n=8,2 \mathrm{IE}$ ). $\mathbf{b} R_{\text {te }}$ was not altered by MSC-CM, determined in Ussing chambers ( $\left.n=28-31,2 \mathrm{IE}\right)$. $\mathbf{c}$ No altered metabolic activity was observed in MSC-CM-treated FDLE cells by MTT assays $(n=6,2 \mathrm{IE})$. $\square$ control, $\bullet$ MSC-CM 


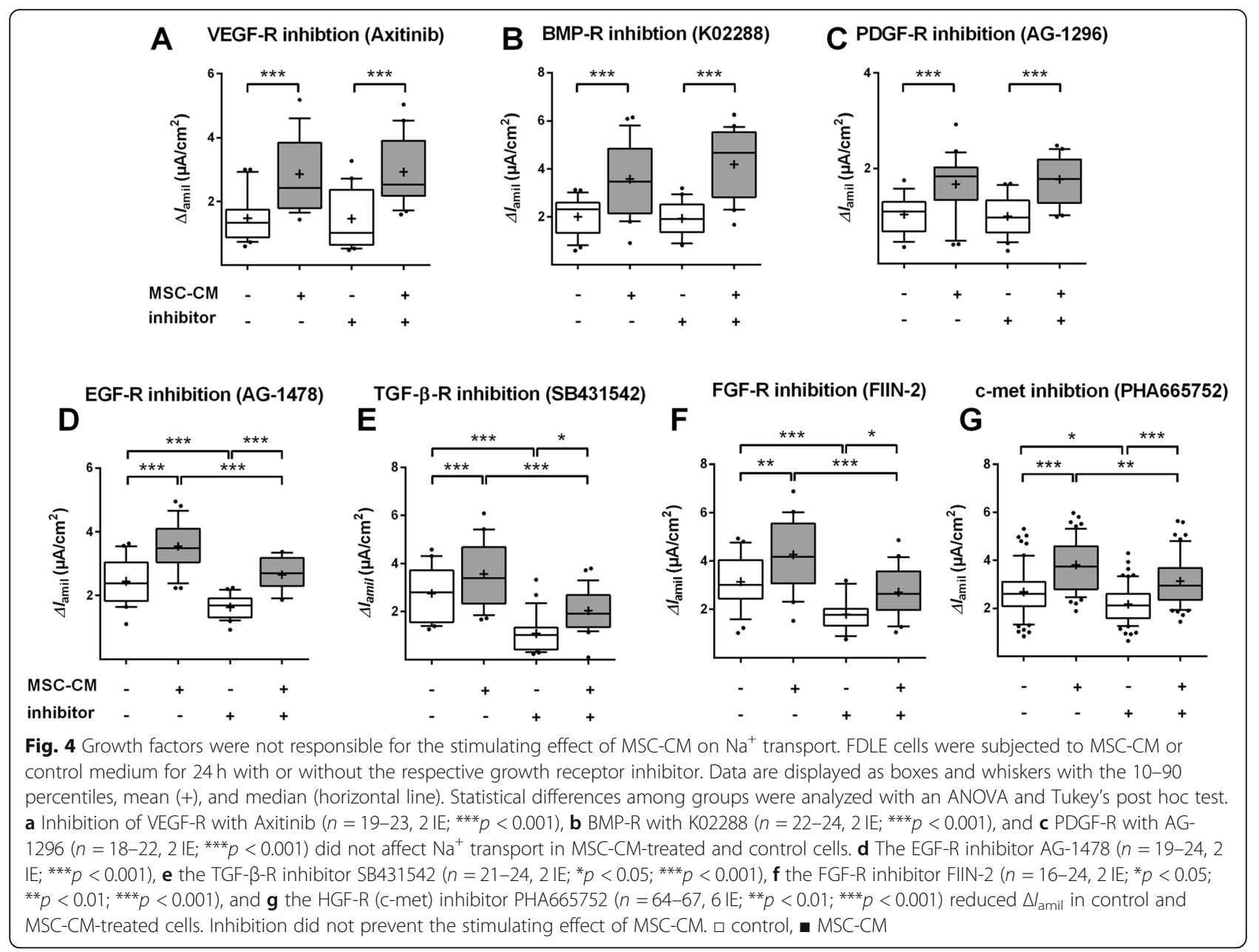

$\mathrm{CM}$ on $\mathrm{Na}^{+}$transport. Previous studies showed that PI3$\mathrm{K}$ and AKT signaling increased $\mathrm{ENaC}$ activity [7, 29]. We therefore determined whether any of these kinases were involved in mediating the MSC-CM effect. Incubation with MSC-CM alone strongly elevated $\Delta I_{\text {amil, com- }}$ pared to control cells $(p<0.001$, Fig. 5a). Inhibition of AKT with Akti $1 / 2$ significantly reduced $\mathrm{Na}^{+}$transport in both, control as well as MSC-CM-treated cells compared to cells cultured without Akti $1 / 2(p<0.001)$. Notably, in the presence of Akti 1/2, MSC-CM was not able to increase $\mathrm{Na}^{+}$transport anymore, suggesting a critical involvement of AKT signaling in the stimulating effect of MSC-CM. Inhibition of AKT signaling had no effect on $R_{\mathrm{te}}$ (Fig. $5 \mathrm{~b}$ ), while $\Delta V_{\text {amil }}$ measurements confirmed that AKT inhibition prevented the stimulating effects of MSC-CM ( $p<0.001$, Fig. 5 c). AKT is activated through PI3-K signaling, which is why we also determined the contribution of the PI3-K by its inhibition with LY294002. MSC-CM incubation significantly enhanced $\mathrm{ENaC}$ activity in FDLE cells compared to control cells $(p<0.001$, Fig. 5 d). However, MSC-CM was also able to increase $\Delta I_{\text {amil }}$ in the presence of LY294002, suggesting that PI3-K signaling is not involved in the stimulating effect of MSC-CM. Indeed, there was no significant difference between MSC-CM-treated cells in the presence or absence of LY294002. However, LY294002 also strongly reduced the $R_{\mathrm{te}}$ of MSC-CM-treated FDLE cells $(p<$ 0.001 , Fig. 5e). As we report the calculated $I_{\mathrm{SC}}$, changes in $R_{\mathrm{te}}$ affect the resulting equivalent $I_{\mathrm{SC}}$. Indeed, $V_{\mathrm{te}}$ revealed a significant reduction of $\Delta V_{\text {amil }}$ in MSC-CMstimulated FDLE cells by LY294002 ( $p<0.001$, Fig. 5f). On the other hand, $\Delta V_{\text {amil }}$ in control cells was not affected by LY294002 and importantly MSC-CM was not able to increase $\Delta V_{\text {amil }}$ in the presence of LY294002. These observations support a critical involvement of PI3-K signaling in the MSC-CM-induced $\mathrm{Na}^{+}$transport. In summary, evidence suggests that both AKT and PI3$\mathrm{K}$ signaling contribute to the enhanced $\mathrm{ENaC}$ activity induced by MSC-CM.

Rac1 signaling contributes to the MSC-CM-mediated ENaC activity

Another mediator activated by RTKs is Rac1, a small Rho-GTPase, that has been shown to positively regulate 


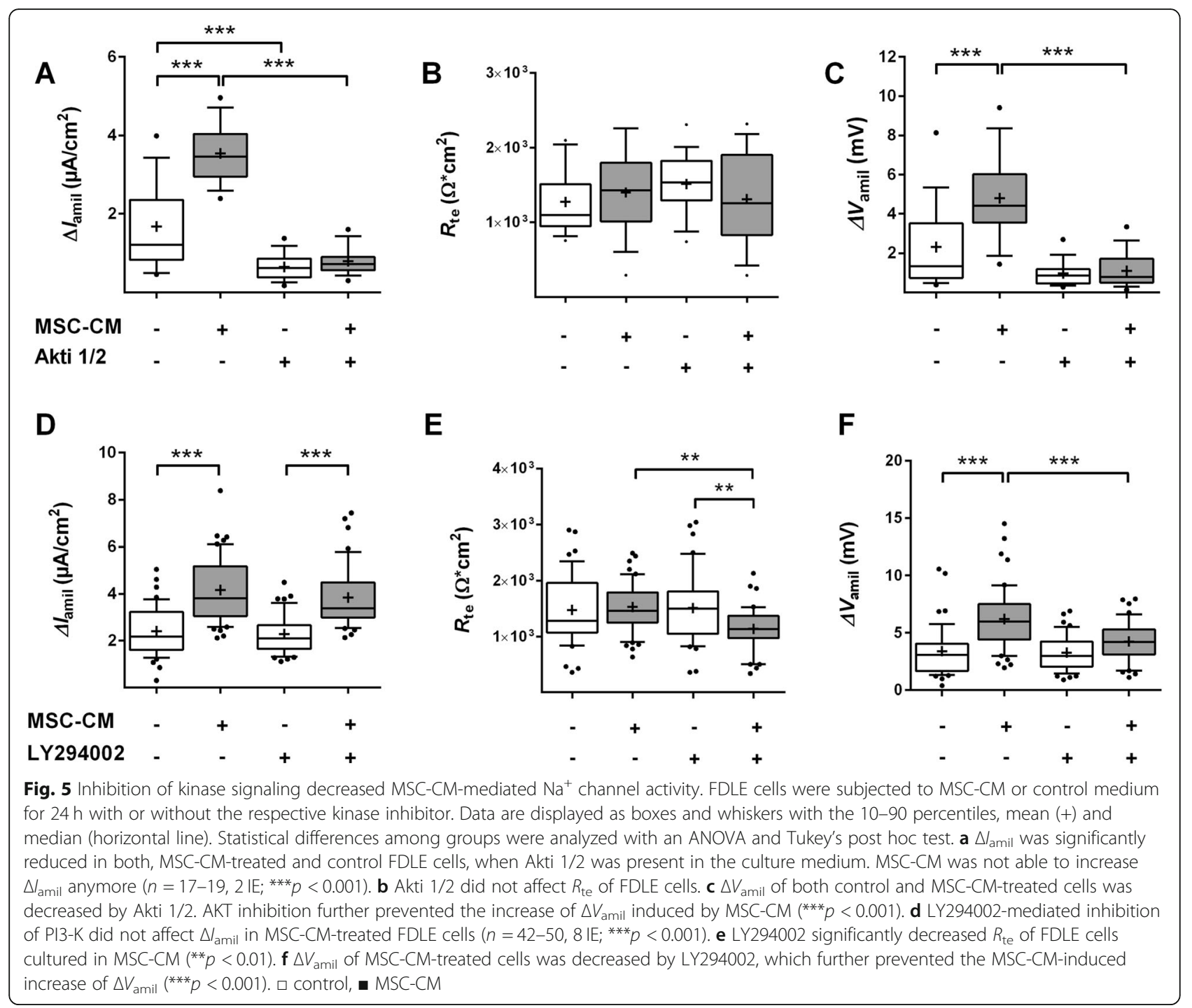

$\mathrm{ENaC}$ activity in the kidney [30]. To analyze the involvement of Rac1 signaling, we used the Rac1 inhibitor Ehop-016 and measured the MSC-CM-induced ENaC activity. MSC-CM strongly elevated $\Delta I_{\text {amil }}$ in the absence and presence of Ehop-016 ( $p<0.001$, Fig. 6a). Rac1 inhibition further significantly decreased $\Delta I_{\text {amil }}$ in MSCCM-treated cells $(p<0.001)$. Notably, $\Delta I_{\text {amil }}$ in control cells was not affected by Rac1 inhibition, suggesting that Rac1 is not required for basal $\mathrm{Na}^{+}$transport, but contributes to the stimulating effect of MSC-CM. However, Rac1 inhibition reduced the $R_{\text {te }}$ of FDLE cells cultivated in MSC-CM $(p<0.05$, Fig. 6b), which affects the calculated $I_{\mathrm{SC}}$. Moreover, the MSC-CM-induced increase of $\mathrm{Na}^{+}$transport in the presence of Ehop-016 was not observed for $\Delta V_{\text {amil }}$ (Fig. 6c). $\Delta V_{\text {amil }}$ was strongly increased by MSC-CM and significantly reduced by the addition of Ehop-016 $(p<0.001)$. In contrast to $\Delta I_{\text {amil }}, \Delta V_{\text {amil }}$ was not different between control and MSC-CM-treated cells in the presence of Ehop-016. These results suggest that Rac1 signaling is involved in MSC-CM-stimulated ENaC activity, but is not solely responsible for the effect.

\section{Discussion}

MSCs are known to secrete important growth factors, and these growth factors have been shown to play a major role in lung development and epithelial integrity (Table 1). However, little is known about the effect of MSCs and their secreted factors on functional and structural lung maturation in the context of prematurity. Our results suggest that MSC-CM improves functional and structural maturation in immature fetal lungs. MSC-CM strongly stimulated $\mathrm{Na}^{+}$transport across fetal lung epithelial cells as well as $\mathrm{Na}^{+}$channel mRNA expression, which has not been shown before. Furthermore, the growth and branching of fetal lung explants were accelerated by MSC-CM. Several studies have shown the 

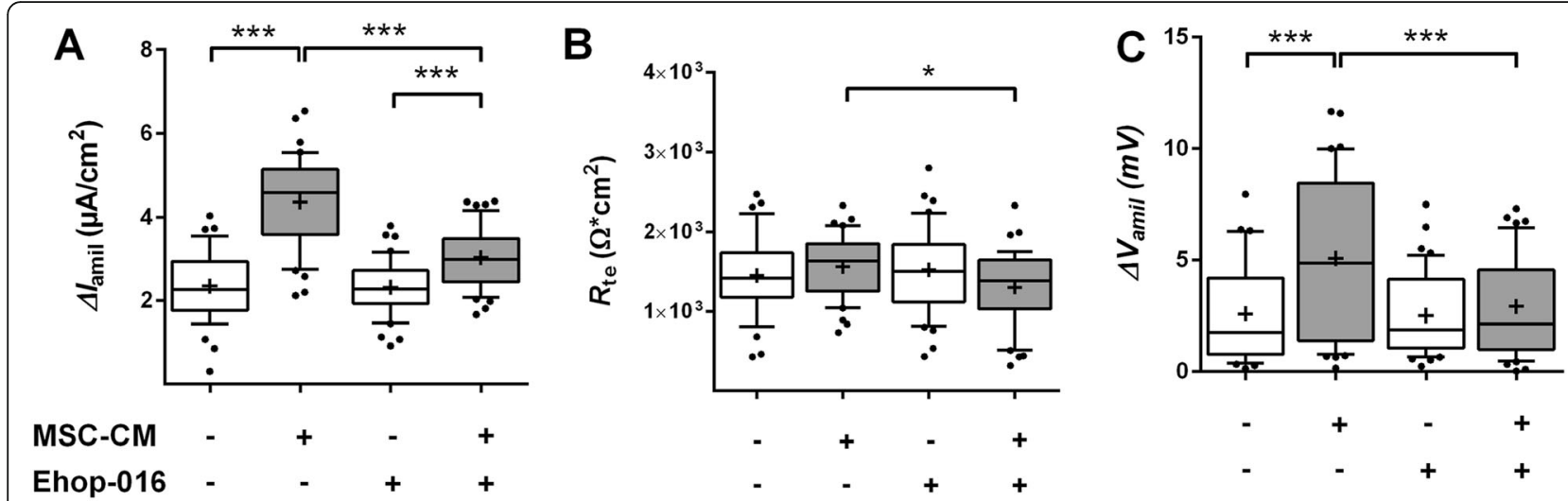

Fig. 6 Inhibition of Rac1 impaired the effect of MSC-CM on $\mathrm{Na}^{+}$transport. FDLE cells were subjected to MSC-CM or control medium for $24 \mathrm{~h}$ with or without the Rac1 inhibitor. Data are displayed as boxes and whiskers with the 10-90 percentiles, mean (+) and median (horizontal line). Statistical differences among groups were analyzed with an ANOVA and Tukey's post hoc test. a $\triangle l_{\text {amil }}$ was significantly reduced by Ehop-016 in FDLE cells cultured in MSC-CM. Controls were not affected by Rac1 inhibition $\left(n=38-44,5 \mathrm{IE}\right.$; $\left.{ }^{* *} p<0.001\right)$. $\mathbf{b} R_{\mathrm{te}}$ of FDLE cells in MSC-CM was decreased by Ehop-016 ( $\left.{ }^{*} p<0.05\right)$. c $\Delta V_{\text {amil }}$ was decreased by Ehop-016 in MSC-CM-treated cells, which prevented the MSC-CM-induced increase of $\left.\Delta V_{\text {amil }}{ }^{* * *} p<0.001\right)$. $\square$ control, $\square$ MSC-CM

Table 1 Effect of growth factors on lung structure and function

\begin{tabular}{|c|c|c|}
\hline & Effects on the lung & Cell/tissue/organ model \\
\hline \multirow[t]{2}{*}{ BMP-4 } & $\downarrow$ proliferation of the lung endoderm; inhibited outgrowth [31] & Fetal mouse lung explant \\
\hline & $\uparrow$ parabronchial smooth muscle cell differentiation [32] & Embryonic mouse lung explant \\
\hline \multirow[t]{4}{*}{ EGF } & $\downarrow$ ENaC activity; Na,K-ATPase activity unchanged [33] & Adult mouse collecting duct \\
\hline & $\uparrow$ fetal pulmonary epithelial cell growth [34] & Fetal rabbit \\
\hline & $\downarrow$ branching in EGF-R deficient lungs [35] & Neonatal mouse lung \\
\hline & $\uparrow$ lung growth in hypoplastic lungs [36] & Fetal rabbit lung \\
\hline \multirow[t]{4}{*}{ FGF-10 } & Maintained alveolar epithelial cell proliferation [37] & Neonatal mouse lung \\
\hline & Directed bipotent progenitors towards ATII lineage [38] & Neonatal rat lung \\
\hline & $\uparrow$ (short-term) Na,K-ATPase activity [39] & A549 cells \\
\hline & $\uparrow$ outgrowth of the lung epithelium [31] & Fetal mouse lung explant \\
\hline \multirow[t]{4}{*}{ HGF } & involved in septal formation [40] & Mouse embryonic lung \\
\hline & $\downarrow$ ENaC activity [41] & Nasal epithelial cells \\
\hline & $\uparrow$ growth and lumen formation [42] & Fetal mouse alveolar epithelial cells \\
\hline & $\uparrow$ epithelial integrity $\left(R_{\mathrm{te}}\right)[43]$ & CFBE41o cells \\
\hline \multirow[t]{4}{*}{ KGF } & $\uparrow$ surfactant gene expression [44] & Fetal rat alveolar epithelial cells \\
\hline & $\uparrow$ epithelial cell proliferation in the airway and alveoli [45] & Adult rat alveolar epithelial cells \\
\hline & $\uparrow \mathrm{AFC}[46]$ & Adult rat alveolar epithelial cells \\
\hline & $\uparrow \mathrm{Na}, \mathrm{K}-\mathrm{ATPase} ; \downarrow$ ENaC mRNA expression [47] & Adult rat alveolar epithelial cells \\
\hline \multirow[t]{5}{*}{ PDGF } & alveolar myofibroblast differentiation \& alveogenesis [48] & PDGF-A mutant mice \\
\hline & $\uparrow$ growth of mesenchymal cells during lung development [49] & Mice overexpressing PDGF-A \\
\hline & $\downarrow$ lung branching [50] & Embryonic mouse lung \\
\hline & $\uparrow \mathrm{ENaC}$ internalization [6] & Mouse lung epithelial \& A549 cells \\
\hline & $\uparrow$ alveolar epithelial to mesenchymal transition [51] & A549 cells \\
\hline \multirow[t]{4}{*}{ VEGF } & $\uparrow$ surfactant protein production [52] & Adult rat alveolar epithelial cells \\
\hline & $\uparrow$ lung angiogenesis [53] & Neonatal rat lung \\
\hline & $\uparrow$ growth of the distal airway epithelial cells [54] & Human fetal lung explant \\
\hline & $\uparrow$ SFTP-B-positive cell number in the airway epithelium [55] & Fetal sheep lung \\
\hline
\end{tabular}


beneficial effect of MSCs in rodent models of BPD, regardless of whether cells or CM were administered [5658]. However, rodent models of BPD are treated with hyperoxia to induce oxygen toxicity which mimics only some pathological features of the disease $[59,60]$. Moreover, newborn rodent pups are viable without $\mathrm{O}_{2}$ support and do not develop immaturity-based respiratory distress. These animal models are thus unsuitable to study the effect of MSCs on lung maturation, and it remains unknown if MSCs induce maturation in immature lung cells. To our knowledge, this is the first study demonstrating a functional improvement of fetal lung cells by MSCs. This is in contrast to previous studies in which MSCs mainly counteracted the experimentally induced damage.

$\mathrm{Na}^{+}$transport mediated by $\mathrm{ENaC}$ and $\mathrm{Na}, \mathrm{K}$-ATPase plays a central role in AFC at birth [61] and is crucial for postnatal survival, as shown by mice lacking the pore-forming $\alpha$-subunit of $\mathrm{ENaC}$ [62]. Preterm infants with RDS had reduced airway epithelial $\mathrm{Na}^{+}$transport [63] and reduced ENaC expression [64] compared with preterm infants without RDS or term infants. Furthermore, the survival of adults with acute RDS (ARDS) is related to the efficiency of their AFC [65] and ARDS, i.e., as a consequence of viral infections like the novel SARS-CoV-2, is associated with high morbidity and mortality [66]. This underlines the importance of therapies that enhance AFC and lung maturation to prevent BPD or ARDS in preterm and adult patients under intensive care. Herein, we showed that FDLE cells incubated in MSC-CM display a higher $\mathrm{ENaC}$ and $\mathrm{Na}, \mathrm{K}$ ATPase activity as well as mRNA expression. MSCs therefore strongly stimulated functional maturation of the fetal lungs in a paracrine manner. The improvement of AFC is of high clinical relevance, and the stimulating effect of MSC-CM on $\mathrm{Na}^{+}$-transport adds to the previously demonstrated beneficial effects of secreted factors raising the translational potential. Similar effects of MSCs on $\mathrm{Na}^{+}$transport were seen in models of acute lung injury (ALI) and organs rejected for transplantation. In detail, MSCs enhanced mRNA expression of $\mathrm{Na}, \mathrm{K}$ ATPase- $\alpha_{1}$ and $-\beta_{1}$ subunits in a lipopolysaccharide (LPS)-induced model of ALI [46]. Furthermore, MSC$\mathrm{CM}$ accelerated $\mathrm{Na}^{+}$transport and epithelial integrity in a model of ALI [67]. Restored AFC was shown by MSCs and their microvesicles in the lungs that were rejected for transplantation $[68,69]$. These studies are in line with our results; however, they were conducted in challenged models or diseased transplants, whereas we show a stimulating effect of MSC-CM on $\mathrm{Na}^{+}$transport in undamaged fetal alveolar cells. Therefore, we can infer that MSCs and their secreted factors stimulate functional maturation of fetal lung cells independent of a noxious cell environment. In addition to $\mathrm{Na}^{+}$transport, secretion of surfactant by mature ATII cells is crucial for perinatal lung transition. FDLE cells cultured with MSC-CM demonstrated elevated mRNA levels of all three surfactant genes. This is consistent with findings that BM-MSCs enhance $S f t p b$ and $S f t p c$ in fetal ATII cells and that resident lung MSCs promote expression of Sftpc when administered in a model of ALI [70, 71].

In addition to functional maturation, we determined the structural maturation of fetal lung explants, because arrested lung development is a hallmark of BPD. We confirmed a stimulating effect of MSC-CM on the growth and branching of fetal lung explants ex vivo. Similar observations have previously been shown for placenta-derived MSCs [21]. The unchanged ratio of the tissue to the total explant area indicates that the MSC$\mathrm{CM}$-induced growth increase is not due to abnormal cell proliferation resulting in tissue hyperplasia. MSC-CM rather led to a proportional tissue growth preserving the tissue to airspace ratio. The stimulation of growth and branching in lung explants and the increase of surfactant mRNA expression confirmed an improved structural maturation of the fetal lungs. The strong effect on functional and structural maturation in the unchallenged cells and lungs shows that the factors secreted by MSCs are not only a treatment option for diseases like BPD or ALI, but also for newborns with immature lungs. To enhance the translation from bench to bedside, it is important to determine the exact factors responsible for the stimulation of functional and structural maturation in future studies. However, the maturational improvements determined in our study already show that MSCs are a powerful tool to combat respiratory diseases associated with lung immaturity or impaired AFC.

Epithelial integrity and metabolic activity were unaltered by MSC-CM. $R_{\mathrm{te}}$ of FDLE monolayers displayed tight monolayers of a high barrier function with little dextran passage even after $24 \mathrm{~h}$. Under these circumstances, MSC-CM exerted no effect on barrier function or metabolic activity. In contrast, MSC-CM stimulated the proliferation and metabolic activity of A549 cells, a human lung epithelial-like cell line [72]. The differential outcome might be due to the cells itself or the used MSC-CM. A549 cells are an immortalized cancer cell line, while we used primary fetal lung epithelial cells. Moreover, the increased proliferation in A549 cells was achieved with 50-fold concentrated MSC-CM [72], in contrast to our study, where we used MSC-CM without concentration. Comparing the results obtained with lung explants to FDLE cells, 24 h MSC-CM incubation might not be long enough to induce proliferation as the growing lung explants were cultured over 4 days. The lung explants used in our study were isolated on ED15, within the pseudoglandular stage of lung development, while the FDLE cells were isolated at the late canalicular to 
the early saccular stage. It might be explicable that proliferation (growth) was induced by MSC-CM at earlier stages of development; while functional differentiation was induced in FDLE cells, isolated from fetal pups 24$48 \mathrm{~h}$ prior to birth.

A variety of studies showed that MSCs secrete important factors, e.g., growth or anti-inflammatory factors. The lung mesenchyme and its secreted paracrine factors are indispensable during lung development. After determining the stimulating effect of MSC-CM, we analyzed if specific growth factors, known to play an essential role in lung development (Table 1), are involved. Inhibition of VEGF-R, BMP-R, and PDGF-R did not affect $\mathrm{Na}^{+}$ transport, neither in control nor in MSC-CM-treated FDLE cells. We conclude that VEGF-R, BMP-R, and PDGF-R signaling are not contributing to the basal as well as stimulated $\mathrm{Na}^{+}$transport. To our knowledge, no study has tested the influence of these growth factors on $\mathrm{Na}^{+}$transport and $\mathrm{ENaC}$ function in fetal lung epithelial cells. EGF-R, TGF- $\beta-R$, FGF-R, and HGF-R (c-met) inhibition decreased $\mathrm{Na}^{+}$channel activity in MSC-CMtreated cells and controls. We therefore assume that the reduction of $\mathrm{Na}^{+}$channel activity likely represents a general effect, independent of MSC-CM. Additionally, $\mathrm{Na}^{+}$ channel activity was still higher in MSC-CM-treated FDLE cells compared to controls in the presence of the respective inhibitor. EGF-R, TGF- $\beta$-R, FGF-R, and HGF$R$ (c-met) signaling are thus not responsible for the stimulation of $\mathrm{Na}^{+}$transport by MSC-CM. Previous studies reported contrary results of the EGF-mediated effect on $\mathrm{ENaC}$ activity. Some studies showed a stimulating effect, others demonstrated inhibition of $\mathrm{ENaC}$ by EGF $[5,73,74]$. We observed a decrease of $\mathrm{Na}^{+}$channel activity by EGF-R inhibition that suggests EGF as a positive regulator of $\mathrm{Na}^{+}$transport in FDLE cells. However, other studies of our laboratory demonstrated that EGF reduced $\mathrm{ENaC}$ activity (unpublished communication), suggesting that the inhibitor might affect $\mathrm{Na}^{+}$transport independent of blocking EGF actions. Surprisingly, TGF$\beta-R$ inhibition lowered $\mathrm{Na}^{+}$transport in FDLE cells. TGF- $\beta$ has been shown to block ENaC activity in alveolar cells, and thus, receptor inhibition would be assumed to enhance $\mathrm{Na}^{+}$transport [6]. On the other hand, the presence of TGF- $\beta$ in MSC-CM has not been tested and the TGF- $\beta-R$ inhibitor blocks not only Alk5, but also Alk-4 and Alk-7 [75], which might also affect $\mathrm{Na}^{+}$transport and possibly lead to the obtained results. Key players in lung development are FGFs, e.g., FGF-10 or KGF (FGF-7) and HGF. Inhibition of FGF-R1-4 and HGF-R (c-met) lowered ENaC activity, suggesting that these growth factors have an impact on $\mathrm{ENaC}$ activity. However, neither FGF-R nor HGF-R inhibition prevented the stimulating effect of MSC-CM on $\mathrm{Na}^{+}$channel activity. In conclusion, none of the blocked pathways was involved in the stimulating action of MSC-CM. MSCs induce $\mathrm{Na}^{+}$transport either by a yet unrecognized signaling pathway or growth factors act in concert converging at later steps that are activated by more than one factor.

Since the growth factor analyses did not reveal cellular pathways leading to the enhanced $\mathrm{Na}^{+}$transport, common intracellular signaling cascades were examined. These signaling cascades are activated by RTKs and stimulate $\mathrm{Na}^{+}$transport, especially ENaC. PI3-K/AKT signaling pathway, e.g., activated through insulin or $17 \beta$ estradiol, was shown to stimulate $\mathrm{ENaC}$ activity $[7,29]$. Furthermore, actin and the disruption of actin filaments influences epithelial $\mathrm{Na}^{+}$channels [76]. Actin dynamics are mainly mediated by Rho-GTPases like Rac1, whose signaling pathway is also activated by RTKs and was shown to regulate $\mathrm{ENaC}$ in the kidney [30]. Additionally, several studies have shown convergence of these pathways, where PI3-K promoted Rac1 signaling [77, 78]. Inhibition of $\mathrm{AKT}$ vigorously decreased $\mathrm{ENaC}$ activity in control and MSC-CM-treated FDLE cells. Akti 1/2-mediated AKT inhibition completely abolished the effect of MSC-CM. Although Akti 1/2 also significantly reduced $\Delta I_{\text {amil }}$ in controls, this effect was not seen for $\Delta V_{\text {amil }}$, and $\Delta V_{\text {amil }}$ confirms the prevention of MSC-CM efficacy by Akti 1/2. In contrast to AKT, no effect of the PI3-K inhibitor was seen on $\Delta I_{\text {amil }}$ in control and MSC-CMtreated cells. On the other hand, $\Delta V_{\text {amil }}$ and $R_{\text {te }}$ of MSCCM-treated FDLE cells were decreased by PI3-K inhibition. The increase of $\mathrm{Na}^{+}$transport induced by MSC$\mathrm{CM}$ in the presence of PI3-K inhibition was not evident for $\Delta V_{\text {amil. }}$ In this case, the reduced $R_{\text {te }}$ erroneously lowered the calculated $\Delta I_{\text {amil }}$, making the results of $\Delta V_{\text {amil }}$ more reliable, which suggests that MSC-CM at least partly induced $\mathrm{Na}^{+}$transport via PI3-K signaling. Notably, inhibition of Racl decreased $\mathrm{Na}^{+}$transport in MSC-CM-treated FDLE cells that were not seen in controls. Although MSC-CM was still able to stimulate $\Delta I_{\text {amil }}$ in the presence of the Rac1 inhibitor, this effect was not seen for $\Delta V_{\text {amil }}$. Here, MSC-CM was not able to increase $\Delta V_{\text {amil }}$ after Rac1 inhibition, suggesting that Rac1 signaling contributes at least in part to the stimulating effect of MSC-CM on $\mathrm{Na}^{+}$transport. Regarding the results obtained in our study, we propose that yet unknown growth factors secreted by MSCs activate PI3$\mathrm{K}$ and/or Rac1 signaling which leads to an increased $\mathrm{ENaC}$ activity. Furthermore, activated PI3-K can stimulate Rac1, as shown previously [78]. However, the exact mechanisms, secreted factors, and activated pathways responsible for the stimulation of functional and structural lung maturation have to be determined in future studies prior to clinical translation. Nevertheless, it is apparent that factors secreted by MSCs harbor a therapeutic potential for stimulation of lung maturation. 


\section{Conclusion}

In conclusion, within this study, we were able to show that MSCs and their secreted factors in MSC-CM stimulate functional lung maturation by enhancing $\mathrm{Na}^{+}$transport and surfactant protein mRNA expression in FDLE cells. We were also able to show that MSC-CM stimulated the structural maturation of the fetal lungs. In contrast to most studies, these results were obtained without any damaging insult like hyperoxia or LPS. Therefore, the study proposes a stimulation of maturation in the fetal lungs by MSCs instead of their repair capacity shown by others. These results thus suggest that MSCs may exert additional beneficial therapeutic effects on the immature lungs of preterm infants prior to the onset of secondary or chronic lung diseases, which may represent a novel strategy to enhance the arrested lung development.

\section{Supplementary Information}

The online version contains supplementary material available at https://doi. org/10.1186/s13287-020-02028-4.

\section{Additional file 1.}

\begin{abstract}
Abbreviations
AFC: Alveolar fluid clearance; AKT: Protein kinase B; ALI: Acute lung injury; amil max: Maximal ENaC activity; ATIl: Alveolar type II; ARDS: Acute respiratory distress syndrome; BM: Bone marrow; BMP: Bone morphogenetic protein; BMP-R: Bone morphogenetic protein receptor; BPD: Bronchopulmonary dysplasia; BSA: Bovine serum albumin; CM: Conditioned medium; DAPI: 4',6Diamidino-2-phenylindole; DMEM: Dulbecco's modified Eagle's medium; ED: Embryonic day; EGF: Epidermal growth factor; EGF-R: Epidermal growth factor receptor; ENaC: Epithelial $\mathrm{Na}^{+}$channel; EpCAM: Epithelial cell adhesion molecule; FDLE: Fetal distal lung epithelial; FGF: Fibroblast growth factor; FGF-R: Fibroblast growth factor receptor; FITC: Fluorescein isothiocyanate; HE: Hematoxylin and eosin; HGF: Hepatocyte growth factor; HGFR: hepatocyte growth factor receptor (c-met); Ibase: Basal current; IE: Independent experiments; Isc: Short-circuit current;

LPS: Lipopolysaccharide; Mrps18a: Mitochondrial ribosomal protein S18a; MSC: Mesenchymal stem/stroma cell; MSC-CM: Mesenchymal stem cellconditioned medium; MEM: Minimum essential media; MTT: 3-(4,5Dimethylthiazol-2-yl)-2,5-diphenyltetrazolium bromide; NMDG: N-methyl-Dglucamine; ouab max: Maximal Na,K-ATPase activity; PBS: Phosphate-buffered saline; PDGF: Platelet-derived growth factor; PDGF-R: Platelet-derived growth factor receptor; PI3-K: Phosphoinositide 3-kinase; qPCR: Real-time quantitative PCR; Rac1: Ras-related C3 botulinum toxin substrate 1; RDS: Respiratory distress syndrome; $R_{\mathrm{te}}$ : Transepithelial resistance; RTK: Receptor tyrosine kinase; TGF- $\beta$ : Transforming growth factor beta; TGF- $\beta-R$ : Transforming growth factor beta receptor; UC: Umbilical cord; VEGF: Vascular endothelial growth factor; VEGF-R: Vascular endothelial growth factor receptor;

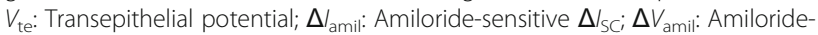
sensitive $\Delta V_{\text {te }}$
\end{abstract}

\section{Acknowledgements}

We wish to thank Dr. Anja Bogen, Jessica Loeffler, and Soeren Pietsch for excellent technical assistance. We acknowledge the support from the Medical Faculty of Leipzig University, as well as support from the Leipzig University for the Open Access Publishing.

\section{Authors' contributions}

JO: manuscript writing, collection and assembly of the data, data analysis, and interpretation; CF: conception and design, data analysis and interpretation; UHT: provision of the study material and interpretation; ML: conception and design, manuscript writing, data analysis and interpretation, provision of the study material. The authors read and approved the final manuscript.

\section{Funding}

This research received no external funding. Open Access funding enabled and organized by Projekt DEAL.

\section{Availability of data and materials}

All data generated or analyzed during this study are either included in this published article [and its supplementary information files] or can be obtained from the corresponding author on reasonable request.

\section{Ethics approval and consent to participate}

The study was approved by the ethical board of the Medical Faculty of Leipzig University. The umbilical cord tissue was collected with the informed consent of the mothers.

\section{Consent for publication \\ Not applicable}

\section{Competing interests}

The authors declare that they have no competing interests.

\section{Author details}

${ }^{1}$ Center for Pediatric Research Leipzig, Department of Pediatrics, Division of Neonatology, University of Leipzig, Liebigstrasse 19, 04103 Leipzig, Germany. ${ }^{2}$ Fraunhofer Institute for Cell Therapy and Immunology, Perlickstrasse 1, 04103 Leipzig, Germany.

Received: 20 August 2020 Accepted: 13 November 2020

Published online: 09 December 2020

\section{References}

1. Bland RD. Lung fluid balance during development. NeoReviews. 2005;6: e255-67. https://doi.org/10.1542/neo.6-6-e255.

2. Brodovich $H$, Hannam V, Seear M, Mullen JB. Amiloride impairs lung water clearance in newborn guinea pigs. J Appl Physiol. 1990;68:1758-62.

3. Fronius $M$, Clauss WG, Althaus M. Why do we have to move fluid to be able to breathe? Front Physiol. 2012;3:146. https://doi.org/10.3389/fphys.2012. 00146.

4. Schmidt C, Klammt J, Thome UH, Laube M. The interaction of glucocorticoids and progesterone distinctively affects epithelial sodium transport. Lung. 2014;192:935-46. https://doi.org/10.1007/s00408-014-9640-3.

5. Falin RA, Cotton CU. Acute downregulation of ENaC by EGF involves the PY motif and putative ERK phosphorylation site. J Gen Physiol. 2007;130:31328. https://doi.org/10.1085/jgp.200709775.

6. Peters DM, Vadász I, Wujak L, Wygrecka M, Olschewski A, Becker C, et al. TGF- $\beta$ directs trafficking of the epithelial sodium channel ENaC which has implications for ion and fluid transport in acute lung injury. Proc Natl Acad Sci U S A. 2014;111:E374-83. https://doi.org/10.1073/pnas.1306798111.

7. Deng W, Li C-Y, Tong J, Zhang W, Wang D-X. Regulation of ENaC-mediated alveolar fluid clearance by insulin via PI3K/Akt pathway in LPS-induced acute lung injury. Respir Res. 2012;13:29. https://doi.org/10.1186/1465-992113-29.

8. Bhalla V, Oyster NM, Fitch AC, Wijngaarden MA, Neumann D, Schlattner U, et al. AMP-activated kinase inhibits the epithelial $\mathrm{Na}+$ channel through functional regulation of the ubiquitin ligase Nedd4-2. J Biol. 2006;281: 26159-69. https://doi.org/10.1074/jbc.M606045200.

9. Walsh BK, Daigle B, DiBlasi RM, Restrepo RD. AARC clinical practice guideline. Surfactant replacement therapy: 2013. Respir Care. 2013;58:36775. https://doi.org/10.4187/respcare.02189.

10. Northway WH, Rosan RC, Porter DY. Pulmonary disease following respirator therapy of hyaline-membrane disease. Bronchopulmonary dysplasia. N Engl J Med. 1967;276:357-68. https://doi.org/10.1056/NEJM196702162760701.

11. Laube M, Stolzing A, Thome UH, Fabian C. Therapeutic potential of mesenchymal stem cells for pulmonary complications associated with preterm birth. Int J Biochem Cell Biol. 2016;74:18-32. https://doi.org/10. 1016/j.biocel.2016.02.023

12. O'Reilly M, Sozo F, Harding R. Impact of preterm birth and bronchopulmonary dysplasia on the developing lung: long-term 
consequences for respiratory health. Clin Exp Pharmacol Physiol. 2013;40: 765-73. https://doi.org/10.1111/1440-1681.12068.

13. Jobe AJ. The New BPD: An arrest of lung development. Pediatr Res 1999;46: 641. doi:https://doi.org/10.1203/00006450-199912000-00007.

14. Baveja R, Christou H. Pharmacological strategies in the prevention and management of bronchopulmonary dysplasia. Semin Perinatol. 2006;30:20918. https://doi.org/10.1053/j.semperi.2006.05.008.

15. Lv F-J, Tuan RS, Cheung KMC, Leung VYL. Concise review: the surface markers and identity of human mesenchymal stem cells. Stem Cells. 2014; 32:1408-19. https://doi.org/10.1002/stem.1681.

16. Ding D-C, Chang Y-H, Shyu W-C, Lin S-Z. Human umbilical cord mesenchymal stem cells: a new era for stem cell therapy. Cell Transplant. 2015;24:339-47. https://doi.org/10.3727/096368915X686841.

17. Leibel S, Post M. Endogenous and exogenous stem/progenitor cells in the lung and their role in the pathogenesis and treatment of pediatric lung disease. Front Pediatr. 2016;4:36. https://doi.org/10.3389/fped.2016.00036.

18. Samper E, Diez-Juan A, Montero JA, Sepúlveda P. Cardiac cell therapy: boosting mesenchymal stem cells effects. Stem Cell Rev Rep. 2013;9:266-80. https://doi.org/10.1007/s12015-012-9353-z.

19. Aslam M, Baveja R, Liang OD, Fernandez-Gonzalez A, Lee C, Mitsialis SA, Kourembanas $S$. Bone marrow stromal cells attenuate lung injury in a murine model of neonatal chronic lung disease. Am J Respir Crit Care Med. 2009:180:1122-30. https://doi.org/10.1164/rccm.200902-0242OC

20. van Haaften T, Byrne R, Bonnet S, Rochefort GY, Akabutu J, Bouchentouf M, et al. Airway delivery of mesenchymal stem cells prevents arrested alveolar growth in neonatal lung injury in rats. Am J Respir Crit Care Med. 2009;180: 1131-42. https://doi.org/10.1164/rccm.200902-01790C.

21. Di Bernardo J, Maiden MM, Jiang G, Hershenson MB, Kunisaki SM. Paracrine regulation of fetal lung morphogenesis using human placenta-derived mesenchymal stromal cells. J Surg Res. 2014;190:255-63. https://doi.org/10. 1016/j.jss.2014.04.013.

22. Leeman KT, Pessina P, Lee J-H, Kim CF. Mesenchymal stem cells increase alveolar differentiation in lung progenitor organoid cultures. Sci Rep. 2019;9: 6479. https://doi.org/10.1038/s41598-019-42819-1.

23. Jassal D, Han RNN, Caniggia I, Post M, Tanswell AK. Growth of distal fetal rat lung epithelial cells in a defined serum-free medium. In Vitro Cell Dev Biol Anim. 1991;27:625. https://doi.org/10.1007/BF02631105.

24. Thome U, Chen L, Factor P, Dumasius V, Freeman B, Sznajder Jl, Matalon S. $\mathrm{Na}, \mathrm{K}$-ATPase gene transfer mitigates an oxidant-induced decrease of active sodium transport in rat fetal ATIl cells. Am J Respir Cell Mol Biol. 2001;24: 245-52. https://doi.org/10.1165/ajrcmb.24.3.3994.

25. Thome UH, Davis IC, Nguyen SV, Shelton BJ, Matalon S. Modulation of sodium transport in fetal alveolar epithelial cells by oxygen and corticosterone. Am J Physiol Lung Cell Mol Physiol. 2003;284:L376-85. https://doi.org/10.1152/ajplung.00218.2002.

26. del Moral P-M, Warburton D. Explant culture of mouse embryonic whole lung, isolated epithelium, or mesenchyme under chemically defined conditions as a system to evaluate the molecular mechanism of branching morphogenesis and cellular differentiation. In: Ward A, Tosh D, editors. Mouse cell culture: methods and protocols. New York: Humana Pr; 2010. p. 71-9. https://doi.org/10.1007/978-1-59745-019-5_5.

27. Nogueira-Silva C, Piairo P, Carvalho-Dias E, Veiga C, Moura RS, Correia-Pinto J. The role of glycoprotein 130 family of cytokines in fetal rat lung development. PLoS One. 2013;8:e67607. https://doi.org/10.1371/journal. pone.0067607.

28. Kaltofen T, Haase M, Thome UH, Laube M. Male sex is associated with a reduced alveolar epithelial sodium transport. PLoS One. 2015;10:e0136178. https://doi.org/10.1371/journal.pone.0136178.

29. Di Qi, He J, Wang D, Deng W, Zhao Y, Ye Y, Feng L. 17ß-estradiol suppresses lipopolysaccharide-induced acute lung injury through PI3K/Akt/SGK1 mediated up-regulation of epithelial sodium channel $(\mathrm{ENaC})$ in vivo and in vitro. Respir Res. 2014;15:159. doi:https://doi.org/10.1186/s12931-014-0159-1.

30. Karpushev AV, Levchenko V, llatovskaya DV, Pavlov TS, Staruschenko A. Novel role of Rac1/WAVE signaling mechanism in regulation of the epithelial Na+ channel. Hypertension. 2011;57:996-1002. https://doi.org/10. 1161/HYPERTENSIONAHA.110.157784.

31. Weaver M, Dunn NR, Hogan BL. Bmp4 and Fgf10 play opposing roles during lung bud morphogenesis. Development. 2000;127:2695-704.

32. Mailleux AA, Kelly R, Veltmaat JM, de Langhe SP, Zaffran S, Thiery JP, Bellusci S. Fgf10 expression identifies parabronchial smooth muscle cell progenitors and is required for their entry into the smooth muscle cell lineage. Development. 2005;132:2157-66. https://doi.org/10.1242/dev.01795.

33. Lee $\mathrm{I}-\mathrm{H}$, Song S-H, Cook DI, Dinudom A. H-Ras mediates the inhibitory effect of epidermal growth factor on the epithelial Na+ channel. PLoS One. 2015; 10:e0116938. https://doi.org/10.1371/journal.pone.0116938.

34. Catterton WZ, Escobedo MB, Sexson WR, Gray ME, Sundell HW, Stahlman MT. Effect of epidermal growth factor on lung maturation in fetal rabbits. Pediatr Res. 1979;13:104-8. https://doi.org/10.1203/00006450-197902000-00004.

35. Miettinen PJ, Warburton D, Bu D, Zhao J-S, Berger JE, Minoo P, et al. Impaired lung branching morphogenesis in the absence of functional EGF receptor. Dev Biol. 1997;186:224-36. https://doi.org/10.1006/dbio.1997.8593.

36. Yoshimura S, Masuzaki H, Miura K, Gotoh H, Moriyama S, Fujishita A, Ishimaru T. Effect of epidermal growth factor on lung growth in experimental fetal pulmonary hypoplasia. Early Hum Dev. 2000;57:61-9. https://doi.org/10.1016/s0378-3782(99)00052-3.

37. Ramasamy SK, Mailleux AA, Gupte W, Mata F, Sala FG, Veltmaat JM, et al. Fgf10 dosage is critical for the amplification of epithelial cell progenitors and for the formation of multiple mesenchymal lineages during lung development. Dev Biol. 2007;307:237-47. https://doi.org/10.1016/j.ydbio. 2007.04.033

38. Chao C-M, Yahya F, Moiseenko A, Tiozzo C, Shrestha A, Ahmadvand N, et al. Fgf10 deficiency is causative for lethality in a mouse model of bronchopulmonary dysplasia. J Pathol. 2017;241:91-103. https://doi.org/10. 1002/path.4834

39. Upadhyay D, Lecuona E, Comellas A, Kamp DW, Sznajder JI. Fibroblast growth factor-10 upregulates Na,K-ATPase via the MAPK pathway. FEBS Lett. 2003;545:173-6. https://doi.org/10.1016/S0014-5793(03)00527-1.

40. Yamamoto H, Yun EJ, Gerber H-P, Ferrara N, Whitsett JA, Vu TH. Epithelialvascular cross talk mediated by VEGF-A and 5HGF6 signaling directs primary septae formation during distal lung morphogenesis. Dev Biol. 2007;308:4453. https://doi.org/10.1016/j.ydbio.2007.04.042.

41. Shen B-Q, Widdicomb JH, Mrsny RJ. Hepatocyte growth factor inhibits amiloride-sensitive $\mathrm{Na}$ +channel function in cystic fibrosis airway epithelium in vitro. Pulm Pharmacol Ther. 1999:12:157-64. https://doi.org/10.1006/pupt. 1999.9999.

42. Sato N, Takahashi H. Hepatocyte growth factor promotes growth and lumen formation of fetal lung epithelial cells in primary culture. Respirology. 1997;2:185-91. https://doi.org/10.1111/j.1440-1843.1997.tb00077.x.

43. Matos AM, Gomes-Duarte A, Faria M, Barros P, Jordan P, Amaral MD, Matos P. Prolonged co-treatment with HGF sustains epithelial integrity and improves pharmacological rescue of Phe508del-CFTR. Sci Rep. 2018;8:13026. https://doi.org/10.1038/s41598-018-31514-2.

44. Chelly N, Mouhieddine-Gueddiche OB, Barlier-Mur AM, Chailley-Heu B, Bourbon JR. Keratinocyte growth factor enhances maturation of fetal rat lung type II cells. Am J Respir Cell Mol Biol. 1999;20:423-32. https://doi.org/ 10.1165/ajrcmb.20.3.3201.

45. Yano T, Mason RJ, Pan T, Deterding RR, Nielsen LD, Shannon JM. KGF regulates pulmonary epithelial proliferation and surfactant protein gene expression in adult rat lung. Am J Physiol Lung Cell Mol Physiol. 2000;279: L1146-58.

46. Li J-W, Wu X. Mesenchymal stem cells ameliorate LPS-induced acute lung injury through KGF promoting alveolar fluid clearance of alveolar type II cells. Eur Rev Med Pharmacol Sci. 2015;19:2368-78.

47. Borok Z, Mihyu S, Fernandes VF, Zhang XL, Kim KJ, Lubman RL. KGF prevents hyperoxia-induced reduction of active ion transport in alveolar epithelial cells. Am J Phys. 1999;276:C1352-60. https://doi.org/10.1152/ ajpcell.1999.276.6.C1352.

48. Boström H, Willetts K, Pekny M, Levéen P, Lindahl P, Hedstrand $H$, et al. PDGF-A signaling is a critical event in lung alveolar myofibroblast development and alveogenesis. Cell. 1996;85:863-73. https://doi.org/10. 1016/50092-8674(00)81270-2.

49. Li J, Hoyle GW. Overexpression of PDGF-A in the lung epithelium of transgenic mice produces a lethal phenotype associated with hyperplasia of mesenchymal cells. Dev Biol. 2001;239:338-49. https://doi.org/10.1006/dbio. 2001.0441.

50. Serra R, Pelton RW, Moses HL. TGF beta 1 inhibits branching morphogenesis and N-myc expression in lung bud organ cultures. Development. 1994;120: 2153-61.

51. Kasai H, Allen JT, Mason RM, Kamimura T, Zhang Z. TGF-beta1 induces human alveolar epithelial to mesenchymal cell transition (EMT). Respir Res. 2005;6:56. https://doi.org/10.1186/1465-9921-6-56. 
52. Compernolle V, Brusselmans K, Acker T, Hoet P, Tjwa M, Beck H, et al. Loss of HIF-2alpha and inhibition of VEGF impair fetal lung maturation, whereas treatment with VEGF prevents fatal respiratory distress in premature mice. Nat Med. 2002;8:702-10. https://doi.org/10.1038/nm721.

53. Thébaud B, Ladha F, Michelakis ED, Sawicka M, Thurston G, Eaton F, et al. Vascular endothelial growth factor gene therapy increases survival, promotes lung angiogenesis, and prevents alveolar damage in hyperoxiainduced lung injury: evidence that angiogenesis participates in alveolarization. Circulation. 2005;112:2477-86. https://doi.org/10.1161/ CIRCULATIONAHA.105.541524.

54. Brown KR, England KM, Goss KL, Snyder JM, Acarregui MJ. VEGF induces airway epithelial cell proliferation in human fetal lung in vitro. Am J Physiol Lung Cell Mol Physiol. 2001;281:L1001-10. https://doi.org/10.1152/ajplung. 2001.281.4.L1001.

55. McGillick EV, Orgeig S, Morrison JL. Structural and molecular regulation of lung maturation by intratracheal vascular endothelial growth factor administration in the normally grown and placentally restricted fetus. J Physiol (Lond). 2016;594:1399-420. https://doi.org/10.1113/JP271113.

56. Ahn SY, Chang YS, Kim SY, Sung DK, Kim ES, Rime SY, et al. Long-term (postnatal day 70) outcome and safety of intratracheal transplantation of human umbilical cord blood-derived mesenchymal stem cells in neonatal hyperoxic lung injury. Yonsei Med J. 2013;54:416-24. https://doi.org/10. 3349/ymj.2013.54.2.416.

57. Sutsko RP, Young KC, Ribeiro A, Torres E, Rodriguez M, Hehre D, et al. Longterm reparative effects of mesenchymal stem cell therapy following neonatal hyperoxia-induced lung injury. Pediatr Res. 2013;73:46-53. https:// doi.org/10.1038/pr.2012.152.

58. Hansmann G, Fernandez-Gonzalez A, Aslam M, Vitali SH, Martin T, Mitsialis SA, Kourembanas S. Mesenchymal stem cell-mediated reversal of bronchopulmonary dysplasia and associated pulmonary hypertension. Pulm Circ. 2012;2:170-81. https://doi.org/10.4103/2045-8932.97603.

59. Bonikos DS, Bensch KG, Northway WH Jr. Oxygen toxicity in the newborn. The effect of chronic continuous 100 percent oxygen exposure on the lungs of newborn mice. Am J Pathol. 1976;85:623-50.

60. O'Reilly M, Thébaud B. Animal models of bronchopulmonary dysplasia. The term rat models. Am J Physiol Lung Cell Mol Physiol. 2014;307:L948-58. https://doi.org/10.1152/ajplung.00160.2014.

61. Matalon S, O'Brodovich H. Sodium channels in alveolar epithelial cells: molecular characterization, biophysical properties, and physiological significance. Annu Rev Physiol. 1999;61:627-61. https://doi.org/10.1146/ annurev.physiol.61.1.627.

62. Hummler E, Barker P, Gatzy J, Beermann F, Verdumo C, Schmidt A, et al. Early death due to defective neonatal lung liquid clearance in alpha-ENaC-deficient mice. Nat Genet. 1996;12:325-8. https://doi.org/10.1038/ng0396-325.

63. Barker PM, Gowen CW, Lawson EE, Knowles MR. Decreased sodium ion absorption across nasal epithelium of very premature infants with respiratory distress syndrome. J Pediatr. 1997;130:373-7. https://doi.org/10. 1016/S0022-3476(97)70198-7.

64. Helve O, Pitkänen OM, Andersson S, O'Brodovich H, Kirjavainen T, Otulakowski G. Low expression of human epithelial sodium channel in airway epithelium of preterm infants with respiratory distress. Pediatr. 2004; 113:1267-72. https://doi.org/10.1542/peds.113.5.1267.

65. Ware LB, Matthay MA. Alveolar fluid clearance is impaired in the majority of patients with acute lung injury and the acute respiratory distress syndrome. Am J Respir Crit Care Med. 2001;163:1376-83. https://doi.org/10.1164/ ajrccm.163.6.2004035.

66. Chen N, Zhou M, Dong X, Qu J, Gong F, Han Y, et al. Epidemiological and clinical characteristics of 99 cases of 2019 novel coronavirus pneumonia in Wuhan, China: a descriptive study. Lancet. 2020;395:507-13. https://doi.org/ 10.1016/S0140-6736(20)30211-7.

67. Goolaerts A, Pellan-Randrianarison N, Larghero J, Vanneaux V, Uzunhan Y, Gille T, et al. Conditioned media from mesenchymal stromal cells restore sodium transport and preserve epithelial permeability in an in vitro model of acute alveolar injury. Am J Physiol Lung Cell Mol Physiol. 2014;306:L97585. https://doi.org/10.1152/ajplung.00242.2013.

68. McAuley DF, Curley GF, Hamid UI, Laffey JG, Abbott J, McKenna DH, et al. Clinical grade allogeneic human mesenchymal stem cells restore alveolar fluid clearance in human lungs rejected for transplantation. Am J Physiol Lung Cell Mol Physiol. 2014;306:L809-15. https://doi.org/10.1152/ajplung. 00358.2013
69. Gennai S, Monsel A, Hao Q, Park J, Matthay MA, Lee JW. Microvesicles derived from human mesenchymal stem cells restore alveolar fluid clearance in human lungs rejected for transplantation. Am J Transplant. 2015;15:2404-12. https://doi.org/10.1111/ajt.13271.

70. Wang L, Shi M, Tong L, Wang J, Ji S, Bi J, et al. Lung-resident mesenchymal stem cells promote repair of LPS-induced acute lung injury via regulating the balance of regulatory T cells and Th17 cells. Inflammation. 2019;42:199210. https://doi.org/10.1007/s10753-018-0884-6.

71. Knoll A, Brockmeyer T, Chevalier R, Zscheppang K, Nielsen H, Dammann C. Adult rat bone marrow-derived stem cells promote late fetal type II cell differentiation in a co-culture model. Open Respir Med J. 2013;7:46-53. https://doi.org/10.2174/1874306401307010046.

72. Chen J, Li Y, Hao H, Li C, Du Y, Hu Y, et al. Mesenchymal stem cell conditioned medium promotes proliferation and migration of alveolar epithelial cells under septic conditions in vitro via the JNK-P38 signaling pathway. Cell Physiol Biochem. 2015;37:1830-46. https://doi.org/10.1159/ 000438545.

73. llatovskaya DV, Pavlov TS, Levchenko V, Staruschenko A. ROS production as a common mechanism of ENaC regulation by EGF, insulin, and IGF-1. Am J Physiol Cell Physiol. 2013;304:C102-11. https:/doi.org/10.1152/ajpcell.00231.2012.

74. Zheleznova NN, Wilson PD, Staruschenko A. Epidermal growth factormediated proliferation and sodium transport in normal and PKD epithelial cells. Biochim Biophys Acta. 1812;2011:1301-13. https://doi.org/10.1016/j. bbadis.2010.10.004.

75. Inman GJ, Nicolás FJ, Callahan JF, Harling JD, Gaster LM, Reith AD, et al. SB431542 is a potent and specific inhibitor of transforming growth factor- $\beta$ superfamily type I activin receptor-like kinase (ALK) receptors ALK4, ALK5, and ALK7. Mol Pharmacol. 2002;62:65-74. https://doi.org/10.1124/mol.62.1.65.

76. Cantiello HF, Stow JL, Prat AG, Ausiello DA. Actin filaments regulate epithelial Na+ channel activity. Am J Physiol Cell Physiol. 1991;261:C882-8. https://doi.org/10.1152/ajpcell.1991.261.5.C882.

77. Campa CC, Ciraolo E, Ghigo A, Germena G, Hirsch E. Crossroads of PI3K and Rac pathways. Small GTPases. 2015;6:71-80. https://doi.org/10.4161/ 21541248.2014.989789.

78. Welch HCE, Coadwell WJ, Stephens LR, Hawkins PT. Phosphoinositide 3kinase-dependent activation of Rac. FEBS Lett. 2003;546:93-7. https://doi. org/10.1016/S0014-5793(03)00454-X.

\section{Publisher's Note}

Springer Nature remains neutral with regard to jurisdictional claims in published maps and institutional affiliations.

Ready to submit your research? Choose BMC and benefit from:

- fast, convenient online submission

- thorough peer review by experienced researchers in your field

- rapid publication on acceptance

- support for research data, including large and complex data types

- gold Open Access which fosters wider collaboration and increased citations

- maximum visibility for your research: over $100 \mathrm{M}$ website views per year

At BMC, research is always in progress.

Learn more biomedcentral.com/submissions 